\title{
EFFECTIVENESS \\ OF THE PROBLEM BASED LEARNING APPROACH IN IMPROVING SKILLS IN WRITING EXPOSITION TEXT
}

\author{
Siti Aisah Sumartini \\ Universitas Suryakancana Cianjur \\ Sitiaisahsumartini@gmail.com
}

\begin{abstract}
This article will describe the effectiveness of the problem based learning approach in improving exposition text writing skills. The method used in the study was an experiment with the design Randomize Pretest-Posttest Control Group with test techniques and questionnaires. The result shows that the average value of the experimental class pretetst 59.97, and posttest 85.76, while the average value of pretest in the control class 58.91, and posttest 67.53. To see the increase in each class, an N-gain test is performed. Based on the test results it was found that in the experimental class there were 18 students who had high writing skills, 12 students with moderate writing skills, and 4 students who had low writing skills, while in the control class there were 3 students who had high writing skills, 16 students with abilities moderate writing, and 15 students who have low writing skills. Based on this, it can be concluded that the Problem Based Learning approach is very effectively used in learning activities in exposition text writing.
\end{abstract}

Keywords: Problem Based Learning, writing, exposition text

\section{PENDAHULUAN}

Mata pelajaran bahasa dan sastra Indonesia adalah salah satu bidang studi yang diajarkan di sekolah. Pelajaran bahasa Indonesia mencakup empat keterampilan berbahasa yang harus dikuasai oleh siswa, antara lain keterampilan menyimak, keterampilan berbicara, keterampilan membaca, dan keterampilan menulis. Keterampilan menulis merupakan urutan yang terakhir dalam keterampilan berbahasa, bila dibandingkan dengan keterampilan berbahasa yang lainnya, keterampilan menulis sulit dikuasai, karena dalam menulis membutuhkan wawasan yang luas mengenai materi yang akan disampaikan serta diperlukan kepiawaian dalam menyampaikan gagasan atau informasi yang akan dituangkan ke dalam sebuah tulisan, dengan menggunakan bahasa sebagai medianya.
Sebagaimana diungkapan Tarigan (2008:22) "Menulis ialah menurunkan atau melukiskan lambang-lambang grafik yang menggambarkan suatu bahasa yang dipahami oleh seseorang, sehingga orang-orang lain dapat membaca lambang-lambang grafik tersebut kalau mereka memahami bahasa dan gambaran grafik itu".

Kegiatan menulis memang beragam, salah satunya adalah kegiatan menulis teks eksposisi. Teks eksposisi merupakan salah satu jenis karangan yang bertujuan untuk menginformasikan tentang sesuatu hal dan diharapkan dapat memperluas pengetahuan pembaca. Sebagaimana ungkapan Nursisto (2000: 41) "Eksposisi atau paparan adalah karangan yang menerangkan atau menjelaskan pokok pikiran yang dapat memperluas wawasan atau pengetahuan pembaca". Teks eksposisi merupakan salah satu materi pelajaran bahasa Indonesia yang perlu 
dikuasai oleh siswa. Namun pada kenyatannya menulis teks eksposisi tidaklah mudah, karena kurangnya minatnya siswa dalam menulis. Sesuai dengan permasalahan tersebut, maka tujuan yang ingin dicapai dalam penelitian ini adalah (1) mengatahui persiapan pembelajaran menulis teks eksposisi dengan pendekatan Problem Based Learning pada siswa kelas X SMK Progresia Cianjur. (2) mengetahui keefektifan pendekatan Projek Based Learning dalam meningkatakan kemampuan menulis teks eksposisi pada siswa kelas X SMK Progresia Cianjur. (3) mengetahui hambatan-hambatan yang dialami oleh siswa dalam menulis teks eksposisi dengan menggunakan pendekatan Problem Based Learning pada siswa kelas X SMK Progresia Cianjur. Pendekatan Problem Based Learning merupakan pendekatan yang di awali dengan sebuah masalah yang didasarkan pada kehidupan nyata, hal ini dimaksudkan agar siswa mampu berpikir kritis dalam memecahkan suatu masalah, seperti yang di ungkapkan oleh Aqib (2014:14), bahwa "Prolem Based Learning adalah suatu pendekatan pembelajaran yang menggunakan masalah dunia nyata sebagai suatu konteks bagi siswa untuk belajar melalaui berpikir kritis dan keterampilan pemecahan masalah dalam rangka memperoleh pengetahuan dan konsep yang esensi dari materi pelajaran". Pencapaian yang ingin dicapai ialah menulis teks eksposisi proses. Pembelajaran menulis teks eksposisi menekankan pada struktur teks eksposisi dan kaidah bahasa yang digunakan dalam menulis teks eksposisi.

\section{METODE}

Dalam penelitian ini digunakan metode eksperimen. Desain eksperimen yang digunakan adalah desain randomize control group pretest-posttst. Desain ini menjadikan populasi dibagi atas dua kelompok yang ditentukan secara acak. Kelompok pertama merupakan kelompok percobaan yang diberikan perlakukan dan kelompok kedua merupakan kelompok yang tidak diberikan perlakuan (kelompok kontrol). Kemudian dicari perbedaan antara mean pengukur keduanya, dan perbedaan ini terjadi karena adanya perbedaan perlakuan.

Populasi dalam penelitian ini adalah siswa kelas X SMK Progresia Cianjur yang berjumlah 225 siswa. Sampel yang diambil berjumlah 68 orang dari kedua kelas, yaitu $\mathrm{X}$ TKJ 2 (34 siswa) dan X TKR 1 (34 siswa).

Dalam penelitian ini instrument yang digunakan adalah lembar tes dan angket. Sesuai dengan instrument tersebut, teknik yang digunakan adalah teknik tes dan angket. Teknik tes digunakan untuk mengumpulkan data sebelum dan sesudah kegiatan pembelajaran menulis teks eksposisi. Sedangkan angket bertujuan untuk mengetahui ada tidaknya faktor penghambat dan penunjang selama kegiatan pembelajaran berlangsung.

\section{HASIL DAN PEMBAHASAN}

Dalam pembelajaran menulis teks ekpsoisi dengan menggunakan pendekatan Problem Based Learning dilaksankan di kelas $\mathrm{X}$ TKJ 2 sebagai kelas eksperimen, pembelajaran menulis teks ekpsoisi dengan menggunkan metode ceramah dilaksanakan di kelas X TKR 1 sebagai kelas kontrol.

Persiapan dilaksankan sebelum kegiatan belajar mengajar. Persiapan pembelajaran merupakan sebuah acuan dalam melaksanakan kegiatan pembelajaran. Segala sesuatu yang dipersiapkan sebelumnya kemudian diaplikasikan dalam pembelajaran. Sehubungan dengan hal tersebut, maka dalam penelitian ini disusun persiapan pembelajaran dalam bentuk silabus, dan Rencana Pelaksanaan Pembelajaran (RPP). Silabus dan RPP tersebut dikembangkan dari kurikulum yang berlaku. Silabus dan Rencana Pelaksaan Pembelajaran (RPP) yang disajikan dalam penelitian ini mengenai pembelajaran teks eksposisi dengan menggunakan pendekatan Problem Based Learning di kelas X SMK Progresia Cianjur. Selain silabus, dikembangkan pula Rencana Pelaksanaan Pembelajaran (RPP) sebagai aplikasi dari 
silabus yang telah disusun. Selanjutnya, untuk mengetahui keefektifan pendekatan Problem Based learning dalam kegiatan menulis teks eksposisi, maka dilakukan tes kepada siswa. Tes dalam menulis teks eksposisi ini merupakan soal uraian, yang didasarkan pada struktur teks eksposisi dan ciri bahasa eksposisi. Adapun kriteria yang digunakan dalam menilai hasil teks eksposisi siswa menurut Nurgiantoro (2001:307) adalah "isi gagasan yang dikemukakan, organisasi isi, tata bahasa, gaya (pilihan stuktur dan kosa kata) dan, ejaan. Setiap unsur tersebut memiliki penilaian yang berbeda. Nilai tesebut mencerminkan pentingnya masingmasing unsur dalam karangan. Isi gagasan yang dikemukakan (skor tertinggi 35), organisasi isi (skor tertinggi 25), tata bahasa (skor tertinggi 20), Gaya yang terdiri dari pilihan struktur dan kosa kata ( skor tertinggi 15), dan ejaan (skor tertinggi 5)". Total skor dari kelima aspek penilaian tersebut adalah 100.

Hasil yang diperoleh dari penelitian menunjukkan bahwa kegiatan menulis teks eksposisi pada kelas eksperimen lebih baik dari pada kelas kontrol. Hal ini dapat dibuktikan dari hasil pengolahan data dengan menggunakan program SPSS. Pada kegiatan pretest nilai rata-rata yang diperoleh kelas eksperimen adalah 59.97, sedangkan rata-rata yang diperoleh kelas kontrol adalah 58.91, dari data rata-rata tersebut, terlihat bahwa kemampuan siswa dalam menulis teks eksposisi tidak jauh berbeda, adapun selisih yang diperoleh adalah 1,06. Sedangkan pada kegiatan posttest nilai rata-rata yang diperoleh kelas eksperimen adalah 85.76, sedangkan rata-rata yang diperoleh kelas kontrol adalah 67.53, dari data rata-rata tersebut terlihat bahwa kemampuan menulis teks eksposisi pada kelas eksperimen jauh lebih baik dibandingkan dengan kelas kontol, dengan pemerolehan selisih sekitar 18,23.

Untuk melihat peningkatan masingmasing kelas dalam kegiatan menulis teks eksposisi pada kelas eksperimen dan kelas kontrol maka dilakukan uji N-gain. Uji Ngain digunakan untuk mengetahui peningkatan kemampuan siswa antara sebelum dan sesudah pemberian perlakuan (treatment) sebagai mana ungkapan Lestari dan Yudhanegara. Menurut Lestari dan Yudhanegara (2015:214) "data N-gain merupakan data yang diperoleh dengan membandingkan selisih skor posttest dan pretest dengan selisih SMI (skor maksimum ideal) dan pretest". Adapun rumus yang digunakan dalam uji N-gain adalah, skor posttest dikurangi skor pretetst dibagi SMI kemudian dikurangi skor pretetst, dengan kriteria penilaian (a) $\mathrm{N}$-gain $\geq 0,70$, nilai tinggi (b) $0,30<\mathrm{N}$-gain $<0,70$ nilai sedang (c) $\mathrm{N}$-gain $\leq 0,30$ nilai rendah. Setelah data diolah dengan uji $\mathrm{N}$-gain, kemudian muncul hasil pengingkatan kemempuan seiswa dalam menulis teks eksposisi antara kelas eksperimen dan kelas kontrol. Untuk lebih jelasnya, dapat dilihat pada grafik berikut ini.

Hasil Uji $N$-gain

Jumlah Peningkatan Kemampuan Menulis Teks Eksposisi

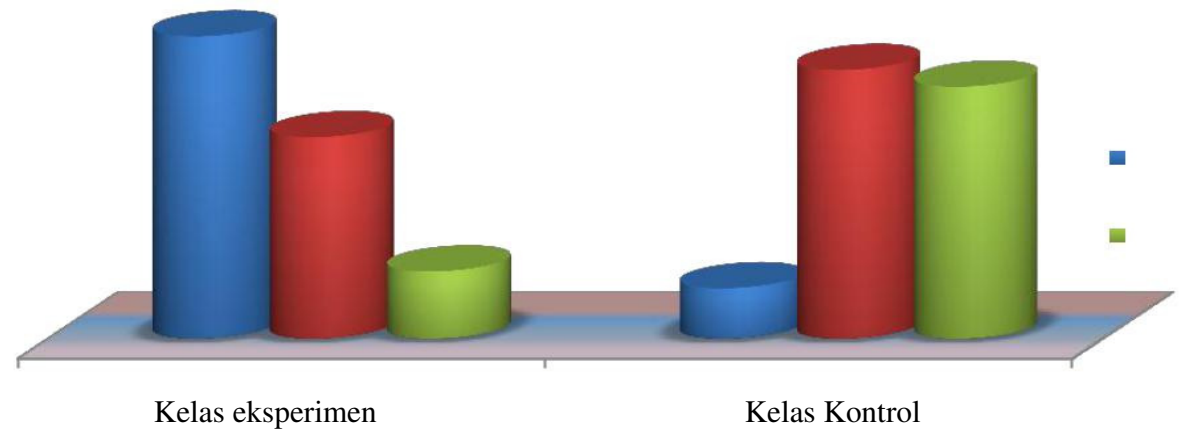


Setelah melakukan uji N-gain, hasil yang diperoleh dalam menulis teks eksposisi dengan menggunakan pendekatan Problem Based Learning untuk kelas eksperimen dan kegiatan menulis teks eksposisi dengan menggunakn metode ceramah untuk kelas kontrol, maka hasil yang diperoleh, pada kelas eksperimen ada 18 siswa yang memiliki kemampuan menulis tinggi, 12 siswa dengan kemampuan menulis sedang, dan 4 siswa yang memiliki kemampuan menulis rendah. Sedangkan pada kelas kontrol ada 3 siswa yang memiliki kemampuan menulis tinggi, 16 siswa dengan kemampuan menulis sedang, dan 15 siswa yang memiliki kemampuan menulis rendah. Berdasarkan hal tersebut, jumlah peningkatan kemampuan siswa antara kelas eksperimen dan kelas kontrol sangat jauh berbeda. Jadi dapat disimpulkan bahwa, kemampuan menulis teks eksposisi siswa yang belajar dengan pendekatan Problem Based Learning lebih baik dari pada siswa yang belajar dengan metode ceramah.

Untuk mengetahu hambatan yang dialami siswa dalam menulis teks eksposisi, maka disebar sebuah angket, yang terdiri dari 10 pertanyaan dan 4 alternatif jawaban. Berdasarkan hasil penelitian, terdapat beberapa faktor yang menjadi penghambat bagi siswa dalam menulis teks ekspsosisi, diantaranya; pada saat proses pembelajaran, umumnya siswa kesulitan dalam menuangkan gagasan atau ide ke dalam sebuah tulisan, hal tersebut terjadi karena kurang memadainya kemampuan berbahasa, serta kurangnya pengetahuan tentang kaidah-kaidah menulis.

Selaian itu, siswa juga kesulitan dalam mencari atau memilah kata yang yang tepat untuk dijadikan sebuah tulisan, hal ini dapat dilihat dari $17,65 \%$ siswa masih mengalami hambatan dalam menulis teks eksposisi.

\section{SIMPULAN}

Penerapan pendekatan Problem Based Learning dalam kegiatan menulis teks eksposisi menunjukkan hal positif, hal ini dapat terlihat dari antusiasme siswa terhadap pembelajaran menulis teks eksposisi dengan menggunkan pendekatan Problem Based Learning. Keterlibatan siswa dalam proses pembelajaran berdampak pada peningkatan persentase tingkat penguasaan materi ajar mereka. Selain itu, jika dibandingkan ratarata dari kedua kelas tersebut nilai yang diperoleh kelas eksperimen lebih baik dibanding kelas kontrol. Dengan begitu, penerapan pendekatan Problem Based Learning dapat meningkatkan hasil belajar siswa.

\section{DAFTAR PUSTAKA}

Arsyad, Azhar. 2013. Media Pembelajaran. Jakarta: Raja Grafindo Persada.

Ningrum. 2018. Studi Penerapan Media Kuis Interaktif Berbasis Game Edukasi Kahoot! Terhadap Hasil Belajar Mahasiswa. Jurnal Ilmiah Ilmu Pendidikan STKIP Persada Sintang. Volume 9 No.1 April 2018 Hal. 22-27. Terdapat pada https://docs.google.com/viewerng/viewer?url=http://jurnal. stkippersada.ac.id/jurnal/index.php/VOX/article/viewFile/ 32/29. [Online] Diunduh 22 Juli 2018.

Official Website 'Kahoot!”. 2017. kahoot.com/company/. Terdapat pada https://kahoot.com/company. [Online] Diunduh pada 13 Juli 2018.

Rafnis. 2018. Pemanfaatan Platform Kahoot Sebagai Media Pembelajaran Interaktif. Jurnal Ilmiah Teknologi Pendidikan Universitas Negeri Padang. Terdapat pada http://ejournal.unp.ac.id/index.php/e-tech/article/ view/101336 [Online] Diunduh pada 10 September 2018.

Rofiarti, F. 2017. Penggunaan Platform Kahoot! dalam Menumbuhkan Jiwa Kompetitif dan Kolaboratif Anak. Pedagogi: Jurnal Anak Usia Dini dan Pendidikan Anak Usia Dini. Volume 3 No.3b. Hal.164-172. Tersedia dalam http://ejournal.unp.ac.id/index.php/etech/article/view/101336. [Online] Diunduh pada 07 Agustus 2018. 